\title{
Antibacterial Resistance in Healthcare-Associated Gram-negative Infections: What Changed in the Past Two Decades?
}

\section{Sag̃lık Bakımı İlișkili İnfeksiyona Yol Açan Gram-negatif Bakterilerde Direnç: Son 20 Yılda Ne Deg̃iști?}

\author{
Pınar AYSERT YILDIZ (IID), Özlem GÜZEL TUNÇCAN (IID), Murat DiZBAY (IID)
}

Department of Infectious Diseases and Clinical Microbiology, Gazi University Faculty of Medicine, Ankara, Turkey

Cite this article as: Aysert Yıldız P, Güzel Tunçcan Ö, Dizbay M. Antibacterial resistance in healthcare-associated gram-negative infections: What changed in the past two decades? FLORA 2021;26(4):704-12.

\begin{abstract}
Introduction: Antimicrobial resistance in healthcare-associated gram-negative microorganisms is rising. Monitoring antimicrobial resistance is crucial for determining infection control programs and planning empirical treatment of patients. In this study, it was aimed to determine the distribution of the causative gram-negative bacteria and monitor the antibiotic susceptibility changes of Pseudomonas aeruginosa, Acinetobacter baumanni, Klebsiella spp. and Escherichia coli.

Materials and Methods: An active and targeted surveillance of healthcare-associated infections is conducted by the Infection Control Committee in high-risk and intensive care units of our hospital. In this study, these surveillance data were used to compare the distribution and antimicrobial susceptibility patterns of gram-negative microorganisms causing healthcare-associated infection in following periods: January-July 1998, January-December 2008 and January-December 2019.

Results: A total of 1635 gram-negative isolates were analyzed, of which 251 were in 1998, 888 in 2008 and 496 in 2019. The most frequent gram-negative bacteria were Acinetobacter baumanni, E. coli, Pseudomonas spp. and Klebsiella spp.. Prevalence of E. coli and Pseudomonas spp. decreased while the prevalence of Klebsiella spp. and Stenotrophomonas maltophilia increased over years. Antimicrobial susceptibilities of beta-lactams, quinolones and aminoglycosides among P. aeruginosa increased over years, only the susceptibility of piperacillin-tazobactam decreased. Among Klebsiella spp., beta-lactams and quinolones had a significant susceptibility loss during the study period. While all Klebsiella isolates were susceptible to meropenem in 1998, only 60\% were susceptible in 2019. There was a significant decrease in susceptibility of ceftazidime, ciprofloxacin and meropenem among E. coli isolates. All tested antibiotics lost significant susceptibility for A. baumanii isolates, especially from 1998 to 2008.

Conclusion: Antimicrobial resistance has had an increasing trend for healthcare-associated isolates of Klebsiella spp., E. coli and Acinetobacter spp. during the last 20 years. Rising carbapenem resistance in Klebsiella spp. has become a major threat to patients in healthcare setting.
\end{abstract}

Key Words: Antimicrobial susceptibility; Antimicrobial resistance; Gram-negative; Hospital acquired; Healthcare-associated

\begin{tabular}{c|c} 
& Received/Geliș Tarihi: 06/06/2021 - Accepted/Kabul Ediliș Tarihi: 12/08/2021 \\
\hline 704 & ${ }^{\circledR}$ Copyright 2021 by Flora. Available on-line at www.floradergisi.org. \\
Available Online Date: 03.01 .2022
\end{tabular}




\title{
Öz
}

\section{Sag̃lık Bakımı İlișkili İnfeksiyona Yol Açan Gram-negatif Bakterilerde Direnç: Son 20 Yılda Ne Deg̃iști?}

\author{
Pınar AYSERT YILDIZ, Özlem GÜZEL TUNCCCAN, Murat DIZBAY
}

Gazi Üniversitesi Tıp Fakültesi, İnfeksiyon Hastalıkları ve Klinik Mikrobiyoloji Anabilim Dalı, Ankara, Türkiye

Giriş: Sağlık hizmeti ilişkili infeksiyona neden olan gram-negatif bakterilere karşı gelişen direnç oranları her geçen gün artmaktadır. Direnç profillerinin takip edilmesi, yatan hastalarda gelişen infeksiyonlarda ampirik antimikrobiyal tedavilerin planlanması ve infeksiyon kontrol programlarının belirlenmesinde önem taşımaktadır. Bu çalışmada, sağlık bakımıla ilişkili infeksiyona neden olan gram-negatif bakterilerin dağılımının belirlenmesi ve en sık karşılaşılan dört mikroorganizma olan Pseudomonas aeruginosa, Acinetobacter baumanni, Klebsiella spp. ve Escherichia coli'nin duyarlııklarındaki değişimlerin izlenmesi amaçlanmıştır.

Materyal ve Metod: Hastanemizin yüksek riskli ve yoğun bakım ünitelerinde sağılk bakımı ilişkili infeksiyonların aktif ve hedefe yönelik sürveyansı Infeksiyon Kontrol Komitesi tarafından yürütülmektedir. Çalışmamızda, bu sürveyans verileri kullanılarak Ocak-Temmuz 1998, Ocak-Aralık 2008 ve Ocak-Aralık 2019 dönemlerinde sağlık bakımı ilişkili infeksiyona neden olan gram-negatif mikroorganizmaların dağılımı ve antimikrobiyal duyarlılık değişimleri incelenmiştir.

Bulgular: Çalışmada, 251'i 1998 yılına, 888'i 2008 yılına ve 496'sı 2019 yılına ait olmak üzere toplam 1635 gram-negatif bakteri incelenmiş olup en sık izole edilen bakteriler yıldan yıla değişen sıkıkta A. baumanni, E. coli, Pseudomonas spp. ve Klebsiella spp.'dir. Yıllar içinde E. coli ve Pseudomonas spp. sıklığı azalırken Klebsiella spp. ve Stenotrophomonas maltophilia sıklığında artış izlenmiştir. Pseudomona spp.'ye karşı piperasilin-tazobaktam dışında diğer tüm antimikrobiyallerin duyarlııklarında artış gözlenmiştir. Klebsiella spp. suşlarında beta-laktam antibiyotikler ve kinolonlara karşı belirgin duyarllık kaybı gözlenmiştir. 1998 yılında \%100 olan meropenem duyarlıı̆ı 2019 yılında \%60'a gerilemiştir. E. coli için seftazidim ve siprofloksasin duyarlılı̆ında belirgin azalma saptanırken meropenem duyarlıı̆̆ 1998'de \%98.7'den 2019'da \%91.6'ya gerilemiştir. A. baumanni için tüm antimikrobiyallerde özellikle 2008 yılında 1998 'e göre belirgin duyarlılık azalması saptanmışır.

Sonuç: Son 20 yılda sağılk bakımı ilişkili infeksiyona yol açan Klebsiella spp., E. coli ve Acinetobacter spp.'ye karşı oluşan antibiyotik dirençleri artış eğilimindedir. Klebsiella spp. izolatlarında artan karbapenem direnci, hastanede yatan hastalar için büyük bir tehdit haline gelmiştir.

Anahtar Kelimeler: Antimikrobiyal duyarlıık; Antimikrobiyal direnç; Gram-negatif; Hastane kökenli; Sağıı bakımı ilişkili

\section{INTRODUCTION}

Healthcare associated infections (HAI) are significant infections which affect the quality of healthcare facilities and lead to preventable morbidity and mortality. The prevalence of HAIs has been shown to be $3.7-6.1 \%$ in surveillance studies, the highest prevalence has been observed in the tertiary/teaching hospitals ${ }^{[1-3]}$. Gram-negative bacteria, particularly Escherichia coli, Klebsiella spp., Pseudomonas spp. and Acinetobacter spp., are important causative agents of $\mathrm{HAI}^{[1]}$. Antibiotic-resistant gram-negative bacteria has globally risen to dangerously high levels in recent years especially with the uncontrolled use of antibiotics. The ability of gram-negative bacteria to up-regulate or acquire genes that encode the antibacterial resistance contributes to the anti- biotic resistance ${ }^{[4]}$. In addition, the decline in discovery and development for new antimicrobials targeting gram-negative organisms has exacerbated the problem. Considering these issues, close monitoring of resistance in gram-negative bacteria is essential in both local and global level ${ }^{[5]}$. Monitoring antimicrobial resistance is also important in determining infection control programs and planning empirical treatment of patients ${ }^{[6]}$.

In this study, it was aimed to determine the distribution of the causative gram-negative bacteria of HAIs and monitor the antibiotic susceptibility changes of the four leading gram-negative bacteria, Pseudomonas aeruginosa, Acinetobacter baumanni, Klebsiella spp. and E. coli, during three periods over the past 20 years. 


\section{MATERIALS and METHODS}

In this study, we evaluated the distribution and susceptibility patterns of gram-negative microorganisms isolated from clinical specimens (endotracheal aspirate, blood, urine, wound, abscess, cerebrospinal fluid, pleural fluid and peritoneal fluid) of patients with HAIs who were followed in high-risk and intensive care units (ICUs) in Gazi University Hospital during three periods: January-July 1998, January-December 2008 and January-December 2019.

In our hospital, an active and targeted HAI surveillance is conducted by the Infection Control Committee in high-risk units and ICUs. Highrisk units include hematology, oncology, stem cell transplantation, solid organ transplantation and newborn units. ICUs include anesthesiology, general surgery, neurosurgery, pediatrics, cardiovascular surgery, neurology, internal medicine and chest diseases. Patients suspected to have HAIs are visited daily by committee nurses and doctors. HAI is diagnosed according to the criteria of "Centers for Diseases Control and Prevention (CDC)", 7,8$]$. A follow-up form including the patients' characteristics and antimicrobial susceptibility results of the causative microorganism is filled for each patient. In this study, causative gram-negative microorganisms of HAIs were examined during the above-mentioned periods. Data were collected from the Infection Control Committee follow-up forms and electronic records of patients.

\section{Microbiological Analysis}

Gram-negative bacteria were identified with conventional methods and antimicrobial susceptibility testing was performed with agar dilution method in the routine microbiology laboratory in 1998 and 2008. In 2019, unlike previous periods, bacterial identification and antimicrobial susceptibility testing were performed with automated systems (MALDI-TOF MS, Bruker, Germany; VITEK-2, bioMerieux, France). The Clinical and Laboratory Standards Institute (CLSI) criteria were used for the interpretation of antimicrobial susceptibility testing results in 1998 and 2008 while the European Committee for Antimicrobial Susceptibility Testing (EUCAST) standards were used in 2019 for the same purpose.

\section{Statistical Analysis}

Chi-square test was used for statistical analysis. A value of $\mathrm{p}<0.05$ was considered significant.

The study was approved by Gazi University Ethics Committee with a decision number 08 in 04 May 2021.

\section{RESULTS}

A total of 1635 healthcare associated gram-negative bacteria were identified in this study. Gram-negative microorganisms constituted $60.9 \%(251 / 412)$ of all bacterial isolates in 1998, 76.6\% (888/1222) in 2008 and 79.3\% $(496 / 625)$ in 2019 . The rate of ICU isolates among gram-negative microorganisms was 42\% in 1998, 70\% in 2008 and 64\% in 2019.

The distribution of the causative gram-negative microorganisms and related HAI types is shown in Table 1. The most isolated gram-negative bacteria were Acinetobacter baumanni, $E$. coli, Pseudomonas spp. and Klebsiella spp. with changing frequency from year to year. Among all gram-negative isolates, the rate of $E$. coli and Pseudomonas spp. has decreased while the rate of Klebsiella spp. and Stenotrophomonas maltophilia has increased over a 20-year period.

Figures 1-4 show the change in antibiotic susceptibilities of $P$. aeruginosa, A. baumanni, Klebsiella spp. and E. coli, according to years. Increased susceptibility for all antibiotics except piperacillin-tazobactam was observed for $P$. aeruginosa while a general decrease in the susceptibility of nearly all antibiotics was observed for Acinetobacter spp., Klebsiella spp. and E. coli.

\section{DISCUSSION}

In this study, the distribution of HAIs and antibiotic sensitivity changes were observed in gram-negative bacteria causing HAIs over a 20-year period. The most common HAI types were pneumonia, urinary tract infection and bloodstream infections. Gradual increase in bloodstream infections and other infection types was observed. Most of the bloodstream infections were caused by gram-positive bacteria in previous years. However, in the last years, gram-negative bacteria has an increasing trend probably due to the rise in the number of ICU, hemodialysis 


\begin{tabular}{|c|c|c|c|c|c|}
\hline & $\begin{array}{c}1998(n=251) \\
(n, \%)\end{array}$ & $\begin{array}{c}2008(n=888) \\
(n, \%)\end{array}$ & $\begin{array}{c}2019(n=496) \\
(n, \%)\end{array}$ & $\begin{array}{c}\text { Total }(n=1635) \\
(n, \%)\end{array}$ & $\mathbf{p}$ \\
\hline \multicolumn{6}{|l|}{ Gram-negative microorganisms } \\
\hline Acinetobacter baumanni & $46(18.3)$ & $313(35.2)$ & $116(23.4)$ & $475(29.1)$ & $<0.001$ \\
\hline Escherichia coli & $80(31.9)$ & $196(22)$ & $78(15.7)$ & $354(21.7)$ & $<0.001$ \\
\hline Pseudomonas spp. & $75(29.9)$ & $172(19.4)$ & $67(13.5)$ & $314(19.2)$ & $<0.001$ \\
\hline Klebsiella spp. & $33(13.1)$ & $105(11.8)$ & $132(26.6)$ & $270(16.5)$ & $<0.001$ \\
\hline Enterobacter spp. & $10(4)$ & $40(4.5)$ & $18(3.6)$ & $68(4.2)$ & 0.72 \\
\hline Stenotrophomonas maltophilia & $1(0.4)$ & $25(2.9)$ & $37(7.5)$ & $63(3.9)$ & $<0.001$ \\
\hline Citrobacter spp. & - & $10(1.1)$ & - & $10(0.6)$ & - \\
\hline Proteus spp. & $3(1.2)$ & $9(1)$ & $11(2.2)$ & $23(1.4)$ & 0.18 \\
\hline Serratia spp. & - & $9(1)$ & $14(2.8)$ & $23(1.4)$ & - \\
\hline Burkholderia spp. & $1(0.4)$ & $5(0.6)$ & $16(3.2)$ & $22(1.3)$ & $<0.001$ \\
\hline C. violescens & $2(0.8)$ & - & - & $2(0.1)$ & - \\
\hline Morganella spp. & - & $4(0.5)$ & $1(0.2)$ & $5(0.3)$ & - \\
\hline Other gram-negative bacilli & - & - & $6(1.2)$ & $6(0.4)$ & - \\
\hline \multicolumn{6}{|l|}{ HAI types } \\
\hline Pneumonia & $74(29.5)$ & $411(46.3)$ & $237(45.6)$ & $722(43.5)$ & $<0.001$ \\
\hline Urinary tract infection & $113(45)$ & $174(19.6)$ & $107(20.6)$ & $394(23.7)$ & $<0.001$ \\
\hline Bloodstream infection & $11(4.4)$ & $179(20.2)$ & $202(38.8)$ & $392(23.6)$ & $<0.001$ \\
\hline Surgical site infection & $44(17.5)$ & $65(7.3)$ & $27(5.2)$ & $136(8.1)$ & $<0.001$ \\
\hline Others* & $9(3.6)$ & $59(6.6)$ & $74(14.2)$ & $142(8.5)$ & $<0.001$ \\
\hline
\end{tabular}

\begin{tabular}{|c|c|c|c|c|c|c|c|}
\hline \multicolumn{8}{|c|}{ Klebsiella pneumoniae } \\
\hline \multicolumn{8}{|l|}{$\begin{array}{r}100 \\
90\end{array}$} \\
\hline \multirow{2}{*}{\multicolumn{8}{|c|}{80}} \\
\hline \multicolumn{6}{|l|}{70} & & \\
\hline \multirow{2}{*}{\multicolumn{8}{|c|}{$\begin{array}{l}60 \\
50\end{array}$}} \\
\hline \multirow{2}{*}{\multicolumn{8}{|c|}{40}} \\
\hline & & & & & & & \\
\hline \multirow{2}{*}{\multicolumn{8}{|c|}{$\begin{array}{l}20 \\
10\end{array}$}} \\
\hline & & & & & & & \\
\hline 0 & $\begin{array}{c}\text { Ceftazidime } \\
p=0.22\end{array}$ & $\begin{array}{c}\text { Cefepime } \\
p=0.04\end{array}$ & $\begin{array}{l}\text { Piperacillin- } \\
\text { tazobactam } \\
p<0.001\end{array}$ & $\begin{array}{c}\text { Meropenem } \\
\text { p }<0.001\end{array}$ & $\begin{array}{c}\text { Ciprofloxacin } \\
p<0.001\end{array}$ & $\begin{array}{c}\text { Gentamycin } \\
p=0.27\end{array}$ & $\begin{array}{l}\text { Amikacin } \\
p<0.001\end{array}$ \\
\hline [ 1998 & 45.5 & 60.3 & 45.5 & 100 & 94.1 & 58 & 69.5 \\
\hline - 2008 & 36.2 & 44.8 & 58.1 & 86 & 54.3 & 70.4 & 91.4 \\
\hline 2019 & 29.9 & 35 & 20.7 & 60 & 43.1 & 62.1 & 63.9 \\
\hline
\end{tabular}

Figure 1. Antibiotic susceptibilities of Klebsiella spp. over the years. 


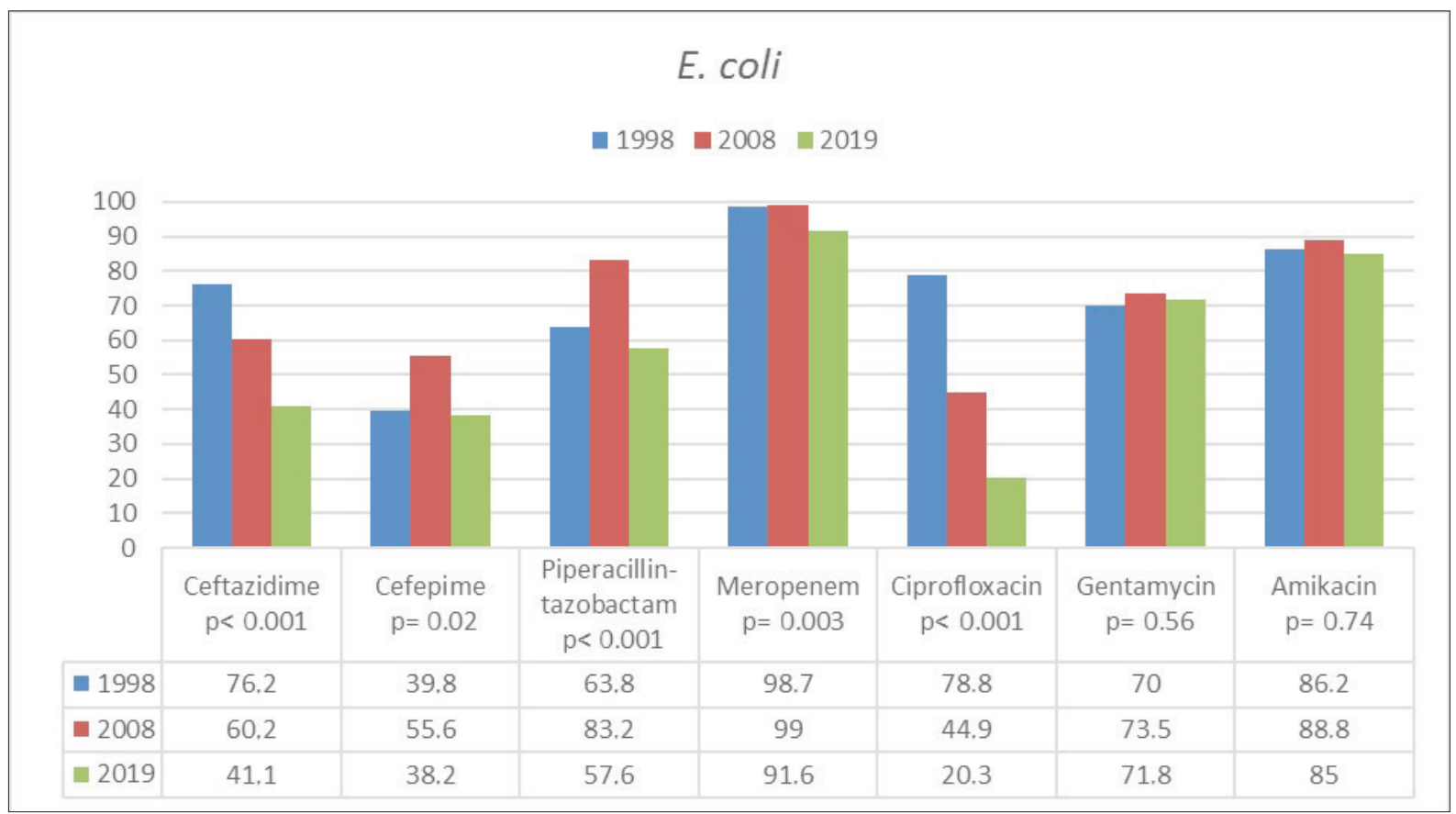

Figure 2. Antibiotic susceptibilities of $E$. coli over the years.

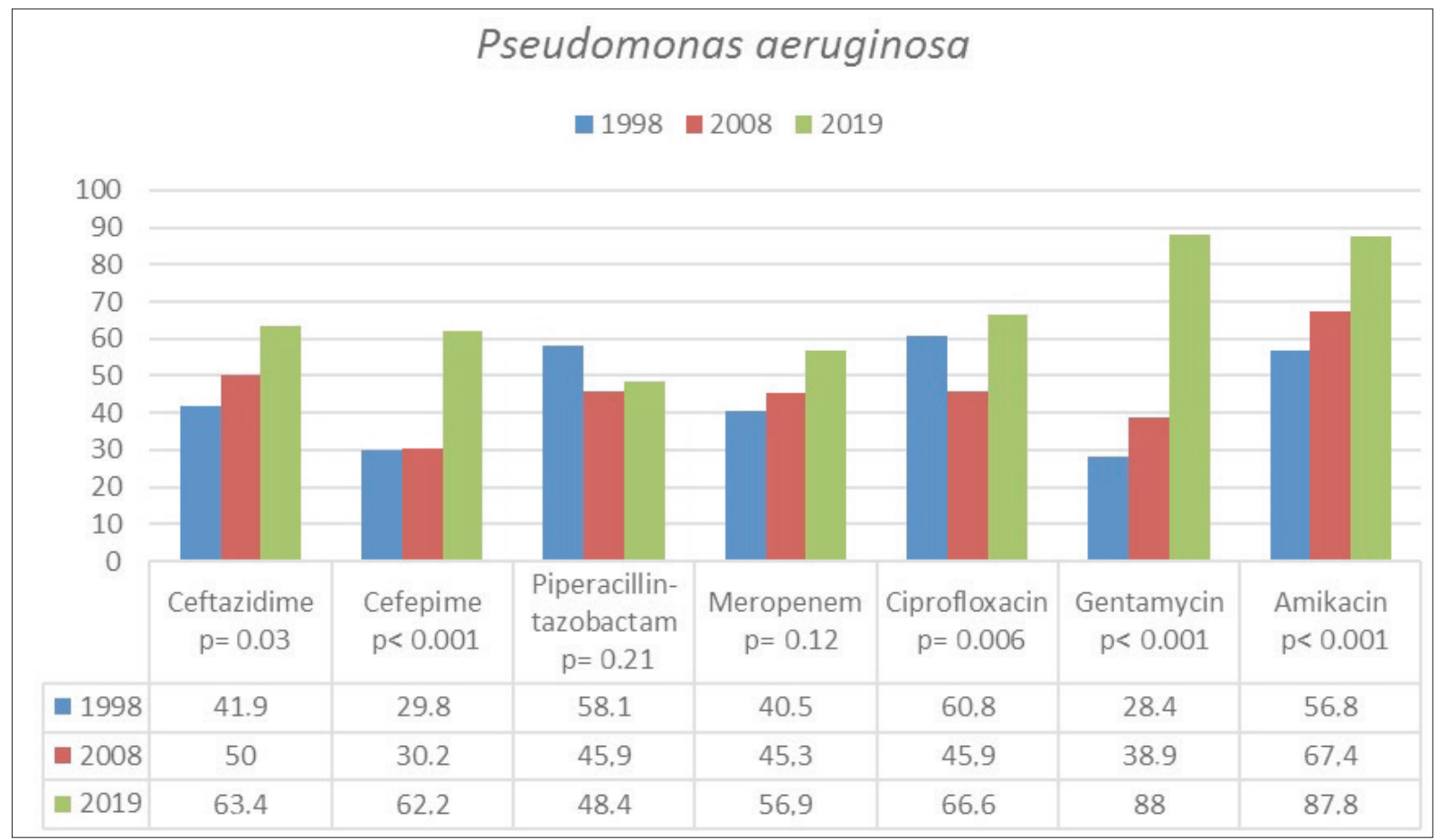

Figure 3. Antibiotic susceptibilities of Pseudomonas aeruginosa over the years.

and immunosuppressive patients in our hospital. Outbreaks of gram-negative microorganisms in the ICU setting also contribute to the rise. Other types of HAIs have gradually risen during the 20year period. Decubitus ulcer infections, which are classified as skin-soft tissue infections, constitute 


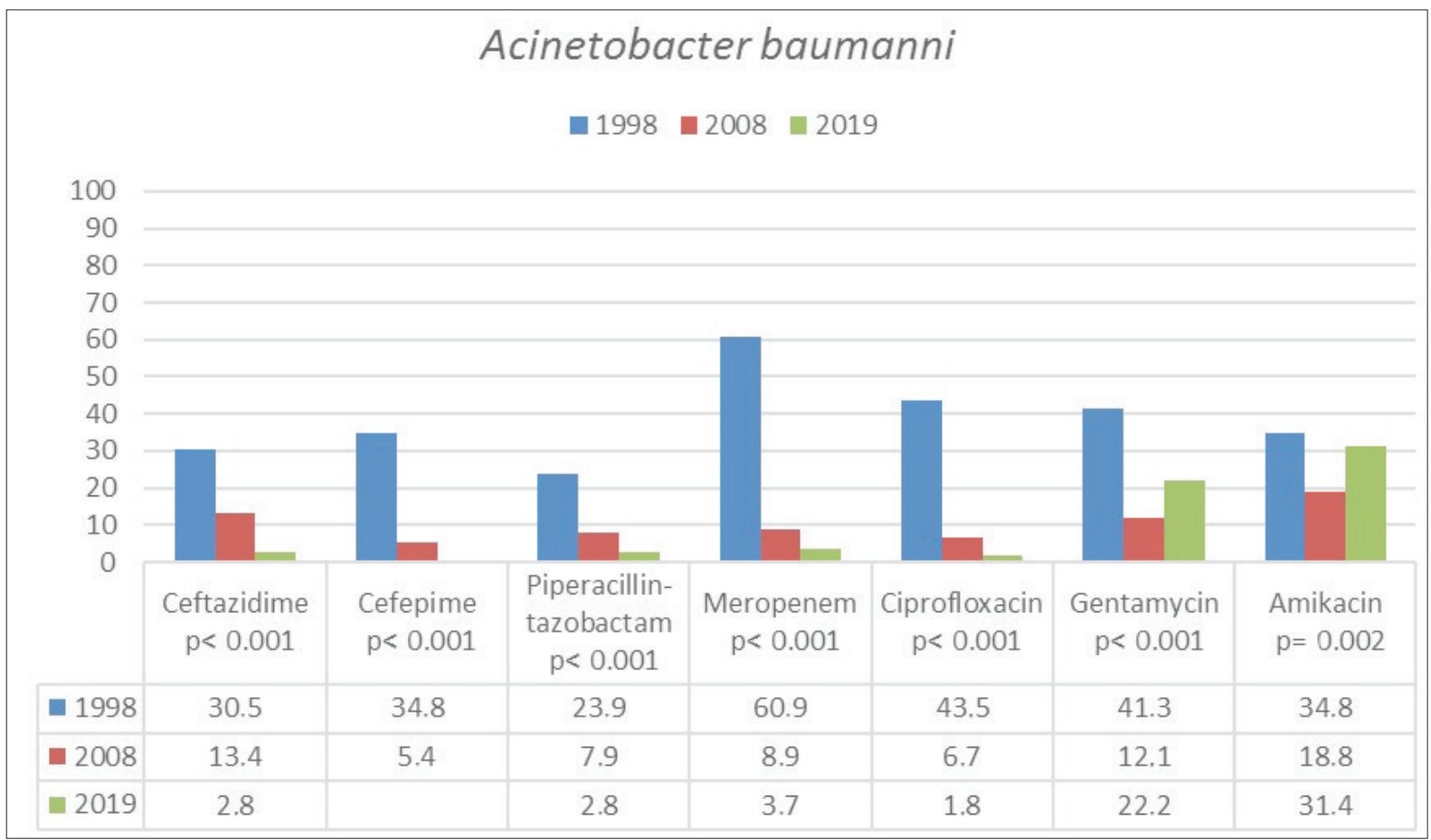

Figure 4. Antibiotic susceptibilities of Acinetobacter baumanni over the years.

an important part of other HAIs in our hospital. The frequency of decubitus ulcers infections has probably increased due to the rising geriatric population and the number of patients receiving palliative care support.

The most common gram-negative bacteria in our study were A. baumanni (29.1\%), E. coli (21.7\%), Pseudomonas spp. (19.2\%) and Klebsiella spp. (16.5\%). There was a prominent increase in the percentage of Klebsiella spp. and $S$. maltophilia isolates among gram-negative bacteria over the years while the incidence of $E$. coli and $P$. aeruginosa has decreased. As a result, Klebsiella spp. became the most common pathogen in 2019 and lead to one fourth of all gram-negative HAIs. Furthermore, a significant reduction in the susceptibility of several antibiotics, especially carbapenems, was observed for Klebsiella spp. While all Klebsiella spp. isolates in 1998 were susceptible to meropenem, only $60 \%$ of them were susceptible in 2019. According to the data of Central Asian and European Surveillance of Antimicrobial Resistance (CAESAR), carbapenem susceptibility rate of invasive Klebsiella spp. isolates in our country in 2019 was 59\%, which is consistent with our finding ${ }^{[9]}$. In Europe, although many countries report low resistance rates for carbapenems, countries like Italy, Romania, the Russian Federation, Serbia and Ukraine have reported proportions between 25\%-50\%, and countries like Belarus and Greece have reported proportions exceeding 50\% in 2019. Meropenem resistance in $K$. pneumoniae has increased from $32.9 \%$ to $58.3 \%$ in Greece and from $1.3 \%$ to $28.5 \%$ in Italy in the last ten years ${ }^{[10]}$. A national surveillance study from Egypt showed a dramatic increase in carbapenem-resistant Klebsiella isolates in ICUs from 20\%-30\% in 2011 to levels of nearly $70 \%$ in $2017^{[11]}$. These data reveal a significant loss of activity for carbapenems against Klebsiella spp. over the last decade. Rising prevalence of ESBL-producing Enterobactericeae increases the carbapenem consumption which imposes a strong selective pressure that triggers the emergence and spread of carbapenem resistant strains. Rapid increase in the carbapenem-resistant Klebsiella spp. is concerning due to high mortality rates, ranging from $30 \%$ to $75 \%$ in severe infections ${ }^{[12]}$. High carbapenem consumption may also be associated with the increasing incidence of $S$. maltophilia, an inherently carbapenem-resistant pathogen, in the last two decades. 
Our study showed a concerning decrease in meropenem susceptibility of $E$. coli isolates, mainly in the last decade (from $99 \%$ in 2008 to $91.6 \%$ in 2019). In Europe, carbapenem resistance in invasive $E$. coli isolates has been reported to be mainly low $(<1 \%)$ in 2018, although Turkey and Greece have reported higher rates (1\%-5\%) ${ }^{[13]}$. According to 2018- CAESAR report, Georgia has the highest carbapenem resistance rate $(\% 11)$ in E. coli isolates among the participating countries, however a limited number of isolates was reported from this country ${ }^{[9]}$. In a metaanalysis, estimated carbapenem resistance is found to be higher than $5 \%$ in E. coli isolates in two Southeast Asia countries, Myanmar and Indonesia ${ }^{[14]}$. These rates should be monitored with caution as carbapenem-resistant $E$. coli may dominate the next decade. Moreover, carbapenemresistant $E$. coli has a greater potential risk for spread in the community ${ }^{[15]}$. There are reports showing that extra-intestinal pathogenic E. coli may be transmitted to humans via the food chain. This transmission has the potential to spread carbapenem-resistant $E$. coli to a larger population $^{[12]}$.

Third generation cephalosporin resistance in Enterobactericeae has shown a significant increase over the years mainly due to the rapid spread of ESBL genes. In our study, ceftazidime was susceptible only in 29\% of Klebsiella spp. and $41 \%$ of $E$. coli isolates in 2019. There was a statistically significant decrease in the susceptibility of ceftazidime for $E$. coli from 1998 to 2019 (from 76.2\% to 41.1\%). In Europe, third generation cephalosporin resistance in invasive $E$. coli isolates, is currently around $5 \%-10 \%$ in Northern countries and rises up to $>50 \%$ in many Southern and Eastern European countries including Turkey ${ }^{[9]}$. SMART study, where antimicrobial susceptibility profiles of pathogens causing urinary tract infections in the Asia-Pacific region, revealed that the overall rate of hospital acquired ESBL- producing E. coli and K. pneumoniae isolates were around 50\% in $2012^{[16]}$. Among the countries in this region, China had the highest rates of ESBL-producing $E$. coli and $K$. pneumoniae ( 60\%) and the highest rates of cephalosporin resistance ${ }^{[16]}$.
Genes responsible from the quinolone resistance are often located on the same plasmid as the ESBL genes and can be co-transferred together leading to resistance to both $3^{\text {rd }}$ generation cephalosporins and quinolones ${ }^{[17]}$. In line with the decrease in the sensitivity of cephalosporins, a significant decrease in the sensitivity of ciprofloxacin was also observed for both Klebsiella spp. (from $94.1 \%$ in 1998 to $43.1 \%$ in 2019) and E. coli (from $78.8 \%$ in 1998 to $20.3 \%$ in 2019) in our study. In the European Region, the overall fluoroquinolone resistance rate has increased from $19.7 \%$ and $28.2 \%$ in 2009 to $23.8 \%$ and $31.2 \%$ in 2019 for invasive E. coli and Klebsiella pneumoniae isolates, respectively $(13,18)$. According to the data of WHO Report on Surveillance of Antibiotic Consumption, the consumption rates of both overall antibiotics and particularly quinolones in our country are very high compared to other European countries ${ }^{[19]}$. This high consumption of antibiotics explains the low antibiotic susceptibility rates in our study.

Pseudomonas aeruginosa is an important nosocomial pathogen with its ability to resist antibiotics by both intrinsic and acquired mechanisms. In our study, a general increase in the susceptibility of antibiotics to $P$. aeruginosa was determined over years with an exception that the susceptibility rate of piperacillin-tazobactam was decreased from $58 \%$ to $48 \%$. Our resistance rate for piperacillin-tazobactam is higher than the rate $(34 \%)$ reported from our country according to the 2019- CAESAR report ${ }^{[9]}$. A previous meta-analysis from our country evaluating the resistance trends of $P$. aeruginosa isolated from various clinical specimens, reported a significant increase in the resistance rate of piperacillintazobactam from $27.4 \%$ in $2007-2011$ to $44.9 \%$ in $2012-2016^{[20]}$. Piperacillin-tazobactam is a highly preferred antibacterial agent in our hospital and this could have contributed to the rising resistance rates. Along with this, relatively less common use of other anti-pseudomonal antibiotics may have reduced the selective pressure and has led to the increased susceptibility.

Acinetobacter baumanni is a threat for hospitalized patients as it frequently contaminates healthcare facility surfaces and shared medical 
equipment, and spread from person to person if adequate infection control measures are not taken ${ }^{[21]}$. Multidrug-resistant Acinetobacter infections have emerged over the past two decades. Most of these infections occur in severely ill patients in the ICU leading to high mortality rates, ranging from $26 \%$ to $68 \%[22,23]$. In our study Acinetobacter spp. was the most prevalent bacteria (28.6\%) among all gramnegative isolates although the frequency has decreased in the last few years. All beta-lactam antibiotics and quinolones had very low activity against Acinetobacter spp. and only one third of all Acinetobacter strains were susceptible to aminoglycosides in 2019. The susceptibility of all antibiotics had significantly decreased from 1998 to 2019. The most concerning decrease was occurred in meropenem resistance (from 60.9\% in 1998 to $3.7 \%$ in 2019). MDR and carbapenem resistant isolates of $A$. baumanni is prevalent all over the world. However, inter-country range in resistance percentages is quite wide (ears net, Bertrand 2012). The percentage of isolates resistant to at least one of the antimicrobial groups (fluoroquinolones, aminoglycosides or carbapenems) ranged between $0 \%$ and 95.8\%, depending on the reporting country in Europe (18)(ears net). A study from our country showed very high resistance rates against meropenem (99\%), ciprofloxacin (99\%), ceftazidime (100\%), amikacin (87\%) and gentamycin (92\%) in A. baumanni isolates obtained from clinical samples of intensive care unit patients ${ }^{[24]}$. These high rates are compatible with findings in our study.

In our study, antimicrobial susceptibility results for colistin and tigecycline were not evaluated. This is a major limitation because colistin and tigecycline has become first-line antibiotic choice for the carbapenem resistant gram-negative bacteria. European Committee on Antimicrobial Susceptibility Testing (EUCAST) guideline recommends performing colistin MIC determination with broth microdilution, which is not routinely used in our hospital ${ }^{[25]}$. In this study, three years in a 20-year time period were selected and evaluated cross-sectionally. Therefore, our data may not exactly reflect the change over 20 years.

\section{CONCLUSION}

Our study revealed that there is a significant decrease in the susceptibility of nearly all antibiotics against healthcare-associated isolates of Klebsiella spp., E. coli and Acinetobacter spp. over the last 20 years. Resistance to third generation cephalosporins and quinolones is quite high among both Klebsiella spp. and E. coli isolates. The incidence of $S$. maltophilia, a naturally carbapenem-resistant microorganism, has increased, probably due to the heavy use of carbapenems for the treatment of ESBL producing gram-negatives. Carbapenem resistance has become a major problem for Acinetobacter baumanni in the last two decades and currently for Klebsiella spp. If adequate measures are not taken and antibiotic stewardship programs are not properly activated, it is projected to be the same for $E$. coli isolates in the next decade.

\section{ETHICS COMMITTEE APPROVAL}

This study was approved by Gazi University Ethics Committee (Decision no: 08, Date: 04 May 2021).

\section{CONFLICT of INTEREST}

None of the authors had conflict of interest.

\section{AUTHORSHIP CONTRIBUTIONS}

Concept and Design: PAY, MD

Data Collection or Processing: PAY, ÖGT

Analysis/Interpretation: PAY, MD

Literature Search: All of authors

Writing: PAY, ÖGT

Final Approval: MD

\section{REFERENCES}

1. Chen $Y$, Zhao JY, Shan X, Han XL, Tian SG, Chen FY, et al. A point-prevalence survey of healthcare-associated infection in fifty-two Chinese hospitals. I Hosp Infect 2017;95(1):105-11.

2. Cairns S, Gibbons C, Milne A, King H, Llano M, MacDonald $L$, et al. Results from the third Scottish National Prevalence Survey: is a population health approach now needed to prevent healthcare-associated infections? I Hosp Infect 2018;99(3):312-7.

3. Deptuła A, Trejnowska E, Ozorowski T, Hryniewicz W. Risk factors for healthcare-associated infection in light of two years of experience with the ECDC point prevalence survey of healthcare-associated infection and antimicrobial use in Poland. J Hosp Infect 2015;90(4):310-5. 
4. Peleg $A Y$, Hooper DC. Hospital-Acquired Infections Due to Gram-Negative Bacteria. N Engl J Med 2010;362:180413.

5. Haque $M$, Sartelli M, Mckimm J, Bakar MA. Health care-associated infections-an overview. Infect Drug Resist 2018;11:2321-33.

6. Karahocagil MK, Yaman G, Göktaş U, Sünnetçioğlu $M$, Çıkman A, Bilici A, et al. Determination of Hospital Infection Pathogens and Resistance Profile. Van Med I $2011 ; 18(1): 27-32$.

7. Garner JS, Jarvis WR, Emori TG, Horan TC, Hughes JM. CDC definitions for nosocomial infections, 1988. Am J Infect Control 1988; 16(3):12840.

8. Centers for Disease Control and Prevention (CDC). CDC/ NHSN Surveillance Definitions for Specific Types of Infections. Access date: 20 January 2021. Available from: http:// www.socinorte.com/wp-content/uploads/2014/06/17pscNosInfDef_current.pdf

9. World Health Organization. Central Asian and European Surveillance of Antimicrobial Resistance Annual report 2019. Access date: 15 January 2021. Available from: https://www.euro.who.int/_data/assets/ pdf_file/0003/418863/53373-WHO-CAESAR-annual-report-2019.pdf

10. European Centre for Disease Prevention and Control (CDC). Surveillance Atlas of Infectious Diseases. Access date: 30 December 2020. Available from: atlas.ecdc.europa.eu/ public/index.aspx

11. Kotb S, Lyman M, Ismail G, Abd El Fattah M, Girgis SA, Etman A, et al. Epidemiology of Carbapenem-resistant Enterobacteriaceae in Egyptian intensive care units using $\mathrm{Na}$ tional Healthcare-associated Infections Surveillance Data, 2011-2017. Antimicrob Resist Infect Control 2020;9(1):19.

12. European Centre for Disease Prevention and Control. Carbapenem-resistant Enterobacteriaceae, second update. Access date: 30 December 2020. Available from: https:// www.ecdc.europa.eu/sites/default/files/documents/carbapenem-resistant-enterobacteriaceae-risk-assessment-rev-2. $p d f$

13. European Centre for Disease Prevention and Control. Antimicrobial resistance in the EU/EEA (EARS-Net) - Annual Epidemiological Report 2019. Access date: 25 January 2021. Available from: <https://www.ecdc.europa.eu/sites/ default/files/documents/surveillance-antimicrobial-resistance-Europe-2019.pdfs

14. Malchione MD, Torres LM, Hartley DM, Koch M, Goodman $J$, et al. Carbapenem and colistin resistance in Enterobacteriaceae in Southeast Asia: Review and mapping of emerging and overlapping challenges. Int J Antimicrob Agents 2019;54(4):381-99.

15. Nordmann P, Naas T, Poirel L. Global spread of carbapenemase producing Enterobacteriaceae. Emerg Infect Dis 2011;17(10):1791-8.
16. Jean SS, Coombs G, Ling T, Balaji V, Rodrigues C, Mikamo $H$, et al. Epidemiology and antimicrobial susceptibility profiles of pathogens causing urinary tract infections in the Asia-Pacific region: Results from the Study for Monitoring Antimicrobial Resistance Trends (SMART), 2010-2013. Int J Antimicrob Agents 2016;47(4):328-34.

17. Tükenmez-Tigen E, Mülazimoğlu L. Extended-Spectrum $\beta$-Lactamases and Their Clinical Importance in Community-Acquired Infections. Klimik Derg 2012;25(3):94-8.

18. European Centre for Disease Prevention and Control. Antimicrobial resistance surveillance in Europe 2009. Access date: 20 January 2021. Available from: https://www.ecdc. europa.eu/sites/default/files/media/en/publications/Publications/1011_SUR_annual_EARS_Net_2009.pdf

19. World Health Organization. WHO report on surveillance of antibiotic consumption: 2016-2018 early implementation. Access date: 20 January 2021. Available from: http://apps. who.int/iris\%0Ahttps://apps.who.int/iris/bitstream/handle /10665/277359/9789241514880-eng.pdf

20. Acar A, Karaahmetoğlu G, Akalın H, Altay AF. Pooled prevalence and trends of antimicrobial resistance in Pseudomonas aeruginosa clinical isolates over the past 10 years in Turkey: A meta-analysis. J Glob Antimicrob Resist 2019;18:64-70.

21. Ayoub Moubareck C, Hammoudi Halat D. Insights into Acinetobacter baumannii: A Review of Microbiological, Virulence, and Resistance Traits in a Threatening Nosocomial Pathogen. Antibiot 2020;12;9(3):119.

22. Bertrand $X$, Dowzicky MJ. Antimicrobial Susceptibility Among Gram-Negative Isolates Collected From Intensive Care Units in North America, Europe, the Asia-Pacific Rim, Latin America, the Middle East, and Africa Between 2004 and 2009 as Part of the Tigecycline Evaluation and Survei. Clin Ther 2012;34(1):124-37.

23. Maragakis LL, Perl TM. Acinetobacter baumannii: Epidemiology, antimicrobial resistance, and treatment options. Clin Infect Dis 2008;46(8):1254-63.

24. Uğur M, Genç S. Three Year Resistance Profile of Acinetobacter baumannii and Pseudomonas aeruginosa Strains Isolated from Intensive Care Units. Turkish I Intensive Care 2019;17(3):130-7.

25. The European Committee on Antimicrobial Susceptibility Testing - EUCAST. Clinical breakpoints - breakpoints and guidance 2021. Access date: 20 January 2021. Available from: https://www.eucast.org/clinical_breakpoints/

\section{Address for Correspondence/Yazıșma Adresi}

\section{Dr. PInar AYSERT YILDIZ}

Gazi Üniversitesi Tıp Fakültesi,

İnfeksiyon Hastalıkları ve

Klinik Mikrobiyoloji Anabilim Dal,

Ankara-Türkiye

E-posta: pinar_aysert@yahoo.com 